\title{
Klasifikasi Wilayah Provinsi Aceh Berdasarkan Tingkat Kerentanan Kasus Malaria Tahun 2015 - 2018
}

\author{
Aja Fatimah Zohra ${ }^{1}$, Samsul Anwar ${ }^{1 *}$, Aida Fitri ${ }^{1}$, Muhammad Haikal Nasution ${ }^{1}$ \\ ${ }^{1}$ Jurusan Statistika, FMIPA, Universitas Syiah Kuala, Banda Aceh \\ *Corresponding Author : samsul.anwar@unsyiah.ac.id \\ Artikel : Diterima Januari 2019 ; Disetujui Maret 2019 ; Publikasi April 2019
}

\begin{abstract}
ABSTRAK
Latar belakang: Malaria merupakan salah satu kasus penyakit yang tidak pernah hilang. World Health Organization (WHO) memperkirakan sebanyak 300 hingga 500 juta orang terinfeksi malaria tiap tahunnya dengan angka kematian berkisar antara 1,5 hingga 2,7 juta pertahun. Pemerintah melalui Rencana Pembangunan Jangka Menengah Nasional (RPJMN) tahun 2015-2019 menargetkan sebanyak 300 kabupaten/kota akan memiliki sertifikasi eliminasi malaria pada tahun 2019. Penelitian ini merupakan penelitian pendahuluan terkait dengan distribusi dan prevalensi kejadian malaria di Provinsi Aceh. Meskipun sebagian besar kabupaten/kota di Provinsi Aceh sudah memiliki sertifikat eliminasi malaria, akan tetapi sebagian wilayah masih terdapat kasus malaria yang relatif tinggi. Penelitian ini bertujuan untuk mengetahui jenis parasit plasmodium yang paling dominan menyebabkan penyakit malaria dan mengklasifikasikan wilayah Provinsi Aceh yang rentan terserang kasus malaria berdasarkan indikator Annual Parasite Incidence (API).

Metode: Penelitian ini adalah penelitian analitik kuantitatif dengan pendekatan data panel. Sampel pada penelitian ini adalah kasus malaria yang terjadi di 23 kabupaten/kota di Provinsi Aceh dari tahun 2015 sampai 2018 yang bersumber dari Dinas Kesehatan Provinsi Aceh. Metode statistik yang digunakan adalah analisis non-parametrik Kruskal-Wallis test, Mann-Whitney test dan K-Means Clustering.

Hasil: Terdapat tiga jenis parasit yang paling dominan menyebabkan kasus malaria di Provinsi Aceh yaitu plasmodium vivax, plasmodium falcifarum dan plasmodium knowlesi. Berdasarkan indikator Annual Parasite Incidence (API), metode K-means clustering menunjukkan bahwa Kabupaten Aceh Jaya, Kota Sabang dan Kabupaten Aceh Selatan merupakan tiga wilayah yang paling rentan untuk terserang kasus malaria di Provinsi Aceh.

Simpulan: Jenis-jenis parasit penyebab kasus malaria tertinggi adalah plasmodium vivax, plasmodium falcifarum dan plasmodium knowlesi. Tiga wilayah di Provinsi Aceh yang paling rentan terserang kasus malaria berdasarkan indikator API adalah Kabupaten Aceh Jaya, Kota Sabang dan Kabupaten Aceh Selatan.
\end{abstract}

Kata kunci: klasifikasi wilayah; k-means clustering; malaria; parasit plasmodium; Provinsi Aceh

\section{ABSTRACT}

Title: Classification of Aceh Province Region Based on Vulnerability Levels of Malaria Cases in 2015 - 2018

Background: Malaria is a case of an emerging disease. World Health Organization (WHO) estimates that 300 to 500 million people are infected with malaria each year with mortality rate ranging from 1.5 to 2.7 million per year. The government through the National Medium Term Development Plan (RPJMN) for 2015-2019 targets as many as 300 districts/cities to have certification of malaria elimination in 2019. This is a preliminary study related to the distribution and prevalence of malaria incidence in Aceh Province. Although most districts/cities in Aceh Province have been awarded malaria elimination certificates, some regions still have relatively high cases of malaria. This study aims to determine the type of plasmodium parasite that is the most dominant cause of malaria and to classify the regions in Aceh Province that is vulnerable to malaria cases based on the Annual Parasite Incidence (API) indicator.

Method: This study is a quantitative analytical research study with panel data approach. The sample in this study was malaria cases that occurred in 23 districts/cities in Aceh Province from 2015 to 2018 obtained from the Aceh 
Provincial Health Office. The statistical methods used in this study were the non-parametric Kruskal-Wallis test, Mann-Whitney test and K-Means Clustering analyses.

Result: There are three types of parasites which are the most dominant causes of malaria cases in Aceh Province, namely plasmodium vivax, plasmodium falcifarum and plasmodium knowlesi. Based on the Annual Parasite Incidence (API) indicator, the K-means clustering method shows that Aceh Jaya District, Sabang City and South Aceh District are the three most vulnerable areas for malaria in Aceh Province.

Conclusion: The types of parasites that cause the highest malaria cases are plasmodium vivax, plasmodium falcifarum and plasmodium knowlesi. Three regions in Aceh Province that are most vulnerable to malaria cases based on API indicator are Aceh Jaya District, Sabang City and South Aceh District.

Keywords: regional classification; k-means clustering; malaria; parasite plasmodium; Aceh Province

\section{PENDAHULUAN}

Menurut World Health Organization (WHO), malaria adalah penyakit yang disebabkan oleh parasit plasmodium yang ditularkan kepada manusia melalui gigitan nyamuk Anopheles betina yang terinfeksi. Penyakit malaria dapat dicegah dan disembuhkan, namun juga dapat menyebabkan kematian apabila tidak ditangani dengan tepat. ${ }^{1}$ Orang yang terkena gejala malaria akan mengalami demam, menggigil, berkeringat, sakit kepala, mual atau muntah. ${ }^{2}$ Pada sebagian besar negara endemis malaria, penyakit ini sering ditemukan pada anak-anak atau pasien yang lebih tua dengan keluhan demam yang sedang mencari perawatan di fasilitas kesehatan. ${ }^{3}$

Indonesia adalah salah satu negara yang berisiko terhadap kasus malaria dengan prevalensi sebesar 1,4\% dan angka insiden sebesar 0,3\% dengan angka Annual Parasite Incidence (API) tahun 2015 sebesar $0,85 \%{ }^{4}$ Salah satu agenda pembangunan nasional yang tertuang dalam Rencana Pembangunan Jangka Menengah Nasional (RPJMN) tahun 2015-2019 adalah meningkatkan kualitas hidup manusia dan masyarakat Indonesia melalui pelaksanaan program Indonesia Sehat. Salah satu indikator dalam sasaran pembangunan kesehatan tersebut adalah jumlah kabupaten/kota yang memiliki sertifikasi eliminasi malaria. ${ }^{5}$ Keputusan Menteri Kesehatan Republik Indonesia Nomor 293/MENKES/SK/IV/2009 tentang Eliminasi Malaria di Indonesia dikeluarkan untuk mewujudkan masyarakat yang hidup sehat, terbebas dari penularan malaria secara bertahap sampai tahun $2030 .{ }^{6}$ Pemerintah menargetkan sebanyak 300 kabupaten/kota akan memiliki sertifikasi eliminasi malaria pada tahun 2019 yang ditetapkan dalam RPJMN tahun 2015-2019.5 Upaya penanggulangan penyakit malaria di Indonesia sudah dimulai sejak tahun 2007 dan dipantau dengan menggunakan indikator API yang merujuk pada kebijakan Kementerian Kesehatan Republik Indonesia. ${ }^{7}$

WHO memperkirakan sebanyak 300 hingga 500 juta orang terinfeksi malaria tiap tahunnya. ${ }^{8}$ Dari jumlah tersebut, terdapat sekitar 3 juta kasus malaria berat (malaria komplikasi) dan kematian akibat malaria. ${ }^{9}$ Sumber lain menyebutkan bahwa sebanyak 1,5 juta hingga 2,7 juta jiwa meninggal setiap tahunnya terutama anak-anak dan ibu hamil. ${ }^{10}$ Kasus malaria merupakan salah satu kasus penyakit yang tidak pernah hilang (emerging). Kejadian Luar Biasa (KLB) kasus malaria terjadi hampir di semua benua, tidak hanya meningkatkan gangguan kesehatan masyarakat, tetapi juga menimbulkan kematian, menurunkan produktivitas kerja, dan dampak ekonomi lainnya termasuk menurunnya pariwisata akibat malaria impor. ${ }^{11}$ Malaria impor merupakan kasus malaria yang terjadi pada seseorang yang berkunjung ke daerah yang rawan timbulnya penyakit malaria dan kemudian kembali ke daerah asalnya yang bukan merupakan wilayah endemis malaria. Beberapa KLB malaria diakibatkan oleh adanya perubahan lingkungan dimana tempat perkembangbiakan potensial nyamuk vektor malaria semakin luas atau semakin bertambah. ${ }^{12}$

Riset Kesehatan Dasar (Riskedas) tahun 2010 menyebutkan bahwa penyebab malaria tertinggi adalah plasmodium falsifarum yaitu sebesar $86,4 \%$ dan plasmodium ovale sebesar $6,9 \%{ }^{2}$ Berdasarkan informasi yang diperoleh dari Jaringan Survey Inisiatif pada tahun 2018, hingga saat ini masih terdapat 4 kabupaten/kota di Provinsi Aceh yang belum memperoleh sertifikasi eliminasi malaria. Keempat kabupaten yang masih terdapat kasus malaria dan berpotensi menularkannya tersebut adalah Kabupaten Nagan Raya, Aceh Barat, Aceh Jaya, dan Aceh Besar. ${ }^{13}$ Meskipun sebagian besar kabupaten/kota di Provinsi Aceh sudah memiliki sertifikat eliminasi malaria, namun kasus malaria masih terjadi di sebagian wilayah seperti di Kabupaten Aceh Selatan. Walaupun telah memperoleh sertifikat eliminasi malaria, namun insiden kasus malaria masih tinggi di kabupaten tersebut.

Penelitian tentang penyakit malaria di Provinsi Aceh telah dilakukan di beberapa wilayah diantaranya Kabupaten Aceh Barat, Kabupaten Nagan Raya, Kabupaten Aceh Jaya dan Kota Sabang. Penelitian di Kabupaten Aceh Barat difokuskan pada analisis faktor risiko kejadian malaria dengan mengambil sampel di wilayah kerja Puskesmas Kuala Bhee Kecamatan Woyla. ${ }^{14}$ Selanjutnya, penelitian di Kabupaten Nagan Raya dilakukan oleh Tim Litbang Biomedis Aceh untuk mengetahui kepadatan vektor penyakit malaria di Kabupaten Nagan Raya. ${ }^{15}$ Penelitian di Kabupaten Aceh Jaya menganalisis faktor-faktor yang berhubungan dengan kejadian malaria berdasarkan Model Community as Partner dengan sampel para pekerja tambang emas di Gunong Ujeun. ${ }^{16}$ Selain itu, 
penelitian lain mengungkapkan bahwa terdapat 11 jenis nyamuk Anopheles di wilayah Aceh Jaya. ${ }^{17}$ Sedangkan penelitian yang dilakukan di Kota Sabang lebih difokuskan pada pemantauan gejala klinis penyakit malaria yang timbul di wilayah endemis. ${ }^{18}$ Kota Sabang merupakan salah satu wilayah endemis penyakit malaria di Provinsi Aceh. Penelitian lain di Kota Sabang dilakukan untuk mendapatkan prevalensi penderita malaria di Pulau Weh, pasca Tsunami pada akhir 2004. ${ }^{19}$ Penelitian lainnya menyimpulkan bahwa terdapat dua jenis parasit plasmodium di wilayah Kota Sabang, yaitu parasit plasmodium falciparum dan plasmodium vivax. ${ }^{20}$

Salah satu langkah awal dalam membantu Pemerintah Aceh maupun kabupaten/kota dalam mengidentifikasi dan mengeliminasi kasus malaria adalah dengan meneliti jenis parasit plasmodium penyebab malaria dan mengklasifikasikan wilayah yang rentan terserang kasus malaria. Sehingga pemerintah dapat bekerja secara lebih fokus pada wilayah dengan tingkat kerentanan kasus malaria yang tinggi. Identifikasi jenis parasit plasmodium penyebab malaria pernah dilakukan di Kecamatan Oba Tengah Kota Tidore Kepulauan. ${ }^{21}$ Klasifikasi wilayah penyebaran penyakit malaria yang pernah dilakukan adalah dengan memanfaatkan sistem teknologi informasi menggunakan teknologi Web-GIS. ${ }^{22}$ Namun penelitian tersebut tidak menggunakan indikator API sebagai dasar klasifikasinya.

Berdasarkan fakta yang telah diuraikan di atas, penelitian ini bertujuan untuk mengetahui jenis parasit plasmodium yang paling dominan menyebabkan penyakit malaria dan mengklasifikasikan wilayah Provinsi Aceh yang rentan terserang kasus malaria berdasarkan nilai API.

\section{MATERI DAN METODE}

Jenis penelitian ini adalah analitik kuantitatif dengan pendekatan data panel. Penelitian ini menggunakan data sekunder berupa kasus malaria yang terjadi di 23 kabupaten/kota di Provinsi Aceh dari tahun 2015 - 2018. Data tersebut bersumber dari Dinas Kesehatan (Dinkes) Provinsi Aceh dan merupakan data panel. Data panel adalah gabungan antara data runtut waktu (time series) dan data silang (cross section). Data yang digunakan merupakan data prevalensi kasus malaria di 23 kabupaten/kota di Provinsi Aceh serta jenis parasit plasmodium penyebab malaria yang dihimpun dalam kurun waktu tahun 2015 - 2018.

Metode analisis yang digunakan dalam penelitian ini adalah metode deskriptif dan inferensia. Analisis deskriptif menggambarkan kasus malaria secara umum. Sedangkan analisis inferensia dilakukan melalui beberapa pengujian statistik. Analisis statistik yang digunakan untuk mengevaluasi jenis parasit plasmodium penyebab kasus malaria adalah analisis Kruskal-Wallis test dengan uji lanjut Mann-Whitney test karena data yang digunakan tidak berdistribusi normal, antar kelompok data tidak memiliki kesamaan varian dan tidak saling independen. Selanjutnya, analisis K-Means Clustering digunakan untuk mengklasifikasikan wilayah Provinsi Aceh yang rentan terserang kasus malaria.

\section{HASIL DAN PEMBAHASAN Analisis Deskriptif}

Data yang digunakan untuk mengevaluasi jenis parasit plasmodium yang paling dominan penyebab malaria di Provinsi Aceh adalah data jumlah penderita penyakit malaria berdasarkan jenis parasit plasmodium. Tabel 1 merangkum karakteristik sampel penderita penyakit malaria berdasarkan jenis kelamin dan kelompok usia.

Tabel 1. Karakteristik sampel penderita penyakit malaria

\begin{tabular}{crr}
\hline Variabel & $\boldsymbol{n}$ & $\boldsymbol{\%}$ \\
\hline Jenis Kelamin & & \\
Laki-laki & 969 & 93,35 \\
Perempuan & 69 & 6,65 \\
Kelompok Usia & & \\
$0-11$ bulan & 0 & 0,00 \\
$1-4$ tahun & 2 & 0,19 \\
$5-9$ tahun & 10 & 0,96 \\
$10-14$ tahun & 10 & 0,96 \\
$\geq 15$ tahun & 1016 & 97,88 \\
\hline
\end{tabular}

Tabel 1 menunjukkan bahwa lebih dari 93\% pasien yang dianalisis dalam penelitian ini berjenis kelamin laki-laki. Selanjutnya jika dilihat berdasarkan kelompok usianya, maka diketahui bahwa 97,88\% pasien berusia di atas atau sama dengan 15 tahun. Data dari Dinkes Provinsi Aceh juga menunjukkan bahwa pasien yang berusia balita hanya sebanyak $0,19 \%$ atau 2 orang saja. Dari total 1.038 kasus yang tercatat di Dinkes Provinsi Aceh, tidak ada satu pun kasus malaria yang terjadi pada bayi usia $0-11$ bulan.

Selanjutnya, data yang digunakan untuk mengklasifikasi wilayah yang rentan terserang penyakit malaria di Provinsi Aceh adalah data jumlah penderita malaria di setiap kabupaten/kota. Gambar 1 menampilkan data jumlah kasus malaria yang disebabkan oleh 6 jenis parasit plasmodium di Provinsi Aceh.

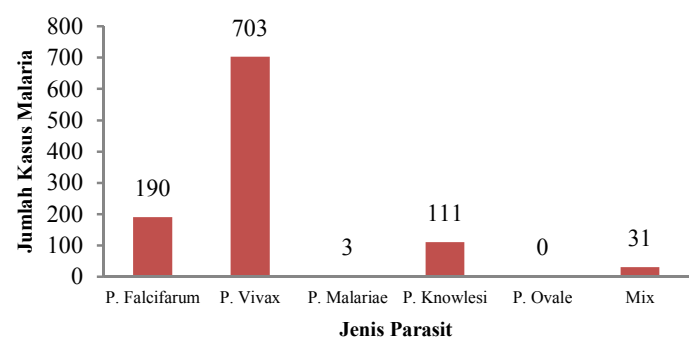

Gambar 1. Jumlah kasus malaria berdasarkan jenis parasit plasmodium 
Selama tahun 2015 - 2018, telah terjadi 1.038 kasus malaria di Provinsi Aceh. Gambar 1 menunjukkan bahwa jenis parasit plasmodium vivax merupakan penyebab kasus malaria tertinggi yaitu sebanyak $703(67,73 \%)$ kasus. Selanjutnya terdapat $190(18,30 \%)$ dan $111(10,69 \%)$ kasus malaria yang masing - masing disebabkan oleh plasmodium falcifarum dan plasmodium Knowlesi. Sedangkan ketiga jenis parasit plasmodium lainnya hanya menyebabkan 34 kasus atau 3,28\%. Diagnosis infeksi malaria dinyatakan positif malaria apabila ditemukan parasit plasmodium dalam darah dengan pemeriksaan secara mikroskop atau memiliki hasil Rapid Diagnostic Test (RDT) yang positif.

Penyebaran kasus malaria juga dapat dilihat secara lebih rinci untuk setiap kabupaten/kota di Provinsi Aceh melalui Gambar 2. Terlihat bahwa Kabupaten Aceh Jaya dan Aceh Selatan merupakan dua kabupaten dengan kasus malaria yang paling banyak di Provinsi Aceh. Terdapat 409 kasus malaria yang terjadi di Kabupaten Aceh Jaya dan 215 kasus malaria di Kabupaten Aceh Selatan. Sedangkan Kabupaten Gayo Lues merupakan satu-satunya kabupaten yang tidak memiliki kasus malaria selama periode waktu penelitian.

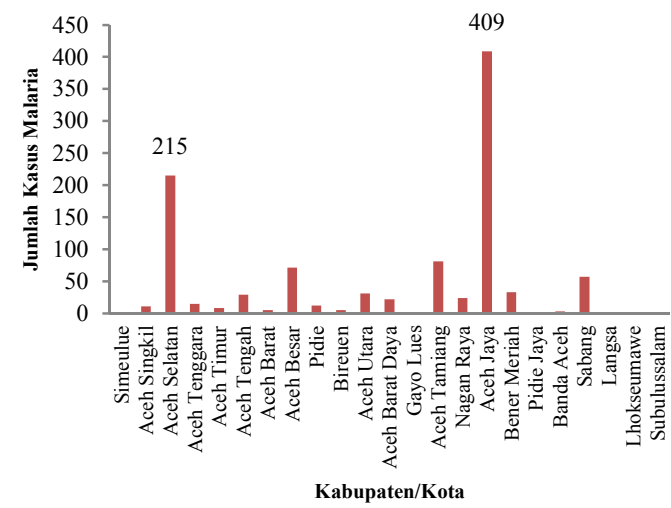

Gambar 2. Jumlah penderita malaria berdasarkan kabupaten/kota

\section{Analisis Inferensial}

\section{Evaluasi Jenis Parasit Penyebab Malaria}

Analysis of Variance (Anova) digunakan untuk menguji hipotesis tentang perbedaan rata-rata lebih dari dua populasi. Terdapat tiga asumsi yang harus terpenuhi dalam pengujian Anova yaitu asumsi normalitas, homogenitas varians dan sampel saling bebas atau independen. ${ }^{23}$ Uji normalitas data dilakukan dengan Shapiro-Wilk test, Homogenitas varians diuji dengan Levene's test dan asumsi independen diuji dengan Chi-Square test.

Pengujian awal mengenai data yang digunakan dalam penelitian ini menunjukkan bahwa data penelitian tidak berdistribusi secara normal, jenis parasit plasmodium yang berbeda menyebabkan kasus malaria dengan nilai varian yang tidak sama serta data penelitian tidak saling independen. Sehingga uji nonparametrik Kruskal-Wallis test digunakan untuk menganalisis jenis parasit plasmodium penyebab malaria di Provinsi Aceh.

Kruskal-Wallis test dapat digunakan sebagai metode alternatif dari Anova. ${ }^{24}$ Pada penelitian ini, Kruskal-Wallis test dapat digunakan untuk melihat ada tidaknya pengaruh jenis parasit plasmodium yang berbeda terhadap kasus malaria di Provinsi Aceh. Hipotesis yang diajukan dalam penelitian ini adalah sebagai berikut:

$\mathrm{H}_{0}: \mathrm{M}_{1}=\mathrm{M}_{2}=\mathrm{M}_{3}=\mathrm{M}_{4}=\mathrm{M}_{5}=\mathrm{M}_{6}$ (semua jenis parasit plasmodium menyebabkan kasus malaria dengan nilai median yang sama)

$\mathrm{H}_{1}: \mathrm{M}_{\mathrm{i}} \neq \mathrm{M}_{\mathrm{j}}$ (minimal terdapat dua jenis parasit plasmodium yang menyebabkan kasus malaria dengan nilai median yang berbeda)

Hasil pengujian statistik memberikan nilai Kruskal-Wallis chi-square sebesar 129,57 dengan $p$ value $<0,001$. Nilai $p$-value yang kecil tersebut menunjukkan bahwa minimal terdapat dua jenis parasit plasmodium yang menyebabkan kasus malaria dengan nilai median yang berbeda. Oleh sebab itu, maka perlu dilakukan pengujian lebih lanjut untuk mengetahui jenis parasit plasmodium mana saja yang memiliki perbedaan nilai median dengan menggunakan uji Mann-Whitney test.

Mann-Whitney test adalah metode yang dapat digunakan untuk membandingkan dua kelompok independen yang tidak membutuhkan asumsi normalitas data. ${ }^{25}$ Dalam penelitian ini, Mann-Whitney test digunakan untuk melihat apakah dua jenis parasit plasmodium yang berbeda menyebabkan kasus malaria dengan nilai median yang berbeda atau tidak. Kedua jenis parasit plasmodium yang diujikan dikatakan menyebabkan kasus malaria dengan nilai median yang berbeda apabila memiliki nilai $p$-value yang lebih kecil dari pada tingkat signifikansi 0,05 .

Tabel 2 merangkum hasil Mann-Whitney test seluruh kemungkinan perbandingan antar dua jenis parasit plasmodium yang berbeda. Pada kasus ini, terdapat 15 kemungkinan perbandingan antar dua jenis parasit plasmodium yang berbeda berdasarkan aturan kombinasi. Nilai statistik yang ditampilkan pada Tabel 2 adalah nilai $p$-value dari seluruh kemungkinan perbandingan yang disajikan dalam bentuk matriks. Matriks tersebut bersifat simetris, artinya perbandingan antara parasit plasmodium $i$ dan $j$ adalah sama dengan perbandingan antara parasit plasmodium $j$ dan $i$. 
Tabel 2. Nilai signifikansi menggunakan Mann-Whitney Test

\begin{tabular}{lcccccc}
\hline Jenis Parasit plasmodium & Falcifarum & Vivax & Malariae & Knowlesi & Ovale & Mix \\
\hline Falcifarum & - & $0,010^{*}$ & $<0,001^{* *}$ & $<0,001^{* *}$ & $<0,001^{* *}$ & $<0,001^{* *}$ \\
Vivax & $0,010^{*}$ & - & $<0,001^{* *}$ & $<0,001^{* *}$ & $<0,001^{* *}$ & $<0,001^{* *}$ \\
Malariae & $<0,001^{* *}$ & $<0,001^{* *}$ & - & $0,005^{*}$ & 0,158 & $0,016^{*}$ \\
Knowlesi & $<0,001^{* *}$ & $<0,001^{* *}$ & $0,005^{*}$ & - & $<0,001^{* *}$ & 0,575 \\
Ovale & $<0,001^{* *}$ & $<0,001^{* *}$ & 0,158 & $<0,001^{* *}$ & - & $<0,001^{* *}$ \\
Mix & $<0,001^{* *}$ & $<0,001^{* *}$ & $0,016^{*}$ & 0,575 & $<0,001^{* *}$ & - \\
\hline
\end{tabular}

"signifikan pada $\alpha=0,05 ;{ }^{* *}$ signifikan pada $\alpha=0,001$

Dari 15 perbandingan antar dua parasit plasmodium tersebut, hanya dua perbandingan yang memiliki nilai $p$-value yang lebih besar dari pada 0,05 yaitu perbandingan antara plasmodium malariae dengan plasmodium ovale dan perbandingan antara plasmodium knowlesi dengan mix (campuran) dengan nilai $p$-valeu masing-masing sebesar 0,158 dan 0,575 (Tabel 2). Hal tersebut menunjukkan bahwa kedua perbandingan jenis parasit plasmodium tersebut memiliki kasus dengan nilai median yang sama. Sedangkan perbandingan antar dua jenis parasit plasmodium lainnya terbukti secara signifikan menyebabkan jumlah kasus dengan nilai median yang berbeda. Melalui Gambar 1 dapat dilihat bahwa plasmodium vivax merupakan jenis parasit plasmodium yang menyebabkan kasus malaria tertinggi di Provinsi Aceh selama rentang waktu penelitian. Sebuah penelitian yang dilakukan di Kabupaten Sumba Tengah Provinsi Nusa Tenggara Timur pada tahun 2015 menyimpulkan bahwa penderita penyakit malaria yang disebabkan oleh plasmodium vivax akan mengalami peningkatan sel limfosit yang cukup signifikan. Selain meningkat pada pasien dengan penyakit malaria yang disebabkan oleh plasmodium vivax, penelitian tersebut juga menunjukkan bahwa penderita malaria yang disebabkan oleh plasmodium falciparum juga mengalami peningkatan jumlah sel limfosit yang signifikan. Penelitian pada 67 pasien malaria tersebut menyimpulkan adanya perbedaan peningkatan jumlah sel limfosit yang signifikan antara plasmodium falciparum (84\%) dan plasmodium vivax (74\%). ${ }^{26}$ Meskipun demikian, penelitian lain terhadap 440 pasien malaria menyimpulkan bahwa lymphocytopenia tidak dapat digunakan sebagai marker diagnosis pada penderita malaria impor terutama pada fase akut. ${ }^{27}$ Dengan demikian, dibutuhkan penelitian yang lebih lanjut mengenai peningkatan sel limfosit pada penderita malaria yang disebabkan oleh jenis plasmodium lainnya.

Sebagai catatan, perbedaan status hematologis pasien malaria yang disebabkan oleh plasmodium falciparum dan plasmodium vivax tidak hanya terbatas pada sel limfosit. Penelitian malaria di RSUP M. Djamil pada periode Januari 2011 hingga Maret 2013 menunjukkan adanya perbedaan yang signifikan pada kadar hemoglobin, hematokrit dan trombosit antara pasien malaria yang disebabkan plasmodium falciparum dengan plasmodium vivax. ${ }^{28}$

\section{Klasifikasi Wilayah Provinsi Aceh Berdasarkan Tingkat Kerentanan Malaria}

Pengklasifikasian suatu kasus atau wilayah dapat dilakukan dengan menggunakan beberapa metode statistik, salah satunya adalah metode K-means clustering. K-means clustering merupakan sebuah metode clustering non-hirarki yang mengelompokan data dalam bentuk satu atau lebih cluster. ${ }^{29}$

Dalam kasus ini, klasifikasi wilayah Provinsi Aceh menurut tingkat kerentanan penyakit malaria didasarkan pada kriteria nilai API. API merupakan indikator untuk menentukan tingkat kebebasan sebuah daerah akan penyakit malaria, dimana nilai API diperoleh dari jumlah kasus malaria dalam setahun dibagi dengan jumlah penduduk dan dikali dengan $1000 .^{7}$ Data yang digunakan adalah data API seluruh kabupaten/kota yang ada di wilayah Provinsi Aceh mulai dari tahun 2015 sampai dengan tahun 2018. Indiktor $A P I$ memiliki empat kategori yaitu No Case Incidence (API =0), Low Case Incidence (LCI) jika nilai API kurang dari 1, Moderate Case Incidence (MCI) jika nilai API berada antara 1 sampai 5 dan High Case Incidence jika nilai API lebih dari 5. Akan tetapi, wilayah kabupaten/kota di Provinsi Aceh hanya memiliki tiga kategori API, yaitu No Case Incidence (kategori 1), Low Case Incidence (kategori 2) dan Moderate Case Incidence (kategori 3) dengan jumlah masing-masing sebanyak 1, 21 dan 1 kabupaten/kota.

Kabupaten Gayo Lues merupakan satu-satunya kabupaten di Provinsi Aceh yang tidak memiliki kasus penyakit malaria atau termasuk kedalam kategori 1. Selanjutnya Kabupaten Aceh Jaya merupakan satusatunya kabupaten yang memiliki jumlah kasus malaria terbanyak di Provinsi Aceh dengan nilai API $<5$ dan termasuk kedalam kategori 3. Sedangkan 21 kabupaten/kota lainnya termasuk ke dalam kategori 2 dengan nilai API yang bervariasi antara 0 sampai dengan 1, sehingga memungkinkan untuk membagi wilayah kabupaten/kota tersebut ke dalam beberapa cluster baru. Wilayah yang berada dalam satu cluster akan memiliki nilai API yang berdekatan, sedangkan wilayah yang berbeda cluster akan memiliki nilai API yang berjauhan. Klusterisasi ini dilakukan untuk memudahkan pihak terkait misalnya Dinas Kesehatan Provinsi Aceh maupun kabupaten/kota untuk mengidentifikasi wilayah - wilayah yang rentan terserang penyakit malaria, sehingga program penanggulangan penyakit malaria dapat difokuskan pada wilayah-wilayah dengan tingkat kerentanan yang 
lebih tinggi. Jumlah cluster yang digunakan dalam penelitian ini adalah sebanyak 3 cluster yaitu Low Case Incidence Cluster 1, Low Case Incidence Cluster 2 dan Low Case Incidence Cluster 3. Cluster 1 merupakan wilayah dengan tingkat kerentanan yang paling rendah dan cluster 3 merupakan wilayah dengan tingkat kerentanan yang paling tinggi untuk kategori Low Case Incidence.

Analisis K-means clustering didasarkan pada jarak antar pengamatan atau data. Jarak terdekat suatu data dengan cluster tertentu akan menentukan dimana letak data tersebut dalam cluster yang tersedia. Hasil klusterisasi dari 21 kabupaten/kota yang termasuk dalam kategori Low Case Incidence (LCI) ditampilkan pada Tabel 3 pada bagian kategori 2. Selain itu, Tabel 3 juga memuat daftar kabupaten/kota yang termasuk dalam kategori 1 (No Case Incidence) dan 3 (Moderate Case Incidence). Kabupaten/kota yang termasuk dalam kategori 1 dan 3 tersebut tidak diikutsertakan dalam analisis $K$-means clustering.

Tabel 3. Klasifikasi wilayah kabupaten/kota di Provinsi Aceh berdasarkan indikator API

\begin{tabular}{|c|c|c|c|}
\hline \multicolumn{2}{|c|}{ Kategori } & \multirow{2}{*}{$\begin{array}{l}\text { Kabupaten/Kota } \\
\text { Kab. Gayo Lues }\end{array}$} & \multirow{2}{*}{$\begin{array}{c}\text { Keterangan } \\
\text { Tidak ada kasus }\end{array}$} \\
\hline Kategori 1 & No Case Incidence & & \\
\hline \multirow[t]{3}{*}{ Kategori 2} & $\begin{array}{c}\text { Low Case Incidence } \\
\text { Cluster } 1\end{array}$ & $\begin{array}{l}\text { Kab. Simeulue, Kab. Aceh Singkil, Kab. Aceh } \\
\text { Tenggara, Kab. Aceh Timur, Kab. Aceh } \\
\text { Tengah, Kab. Aceh Barat, Kab. Aceh Besar, } \\
\text { Kab. Pidie, Kab. Bireuen, Kab. Aceh Utara, } \\
\text { Kab. Aceh Barat Daya, Kab. Aceh Tamiang, } \\
\text { Kab. Nagan Raya, Kab. Bener Meriah, Kab. } \\
\text { Pidie Jaya, Kota Banda Aceh, Kota Langsa, } \\
\text { Kota Lhokseumawe, Kota Subulussalam }\end{array}$ & Rendah Cluster 1 \\
\hline & $\begin{array}{c}\text { Low Case Incidence } \\
\text { Cluster } 2\end{array}$ & Kab. Aceh Selatan & Rendah Cluster 2 \\
\hline & $\begin{array}{c}\text { Low Case Incidence } \\
\text { Cluster } 3\end{array}$ & Kota Sabang & Rendah Cluster 3 \\
\hline Kategori 3 & $\begin{array}{l}\text { Moderate Case } \\
\text { Incidence }\end{array}$ & Kab. Aceh Jaya & Sedang \\
\hline
\end{tabular}

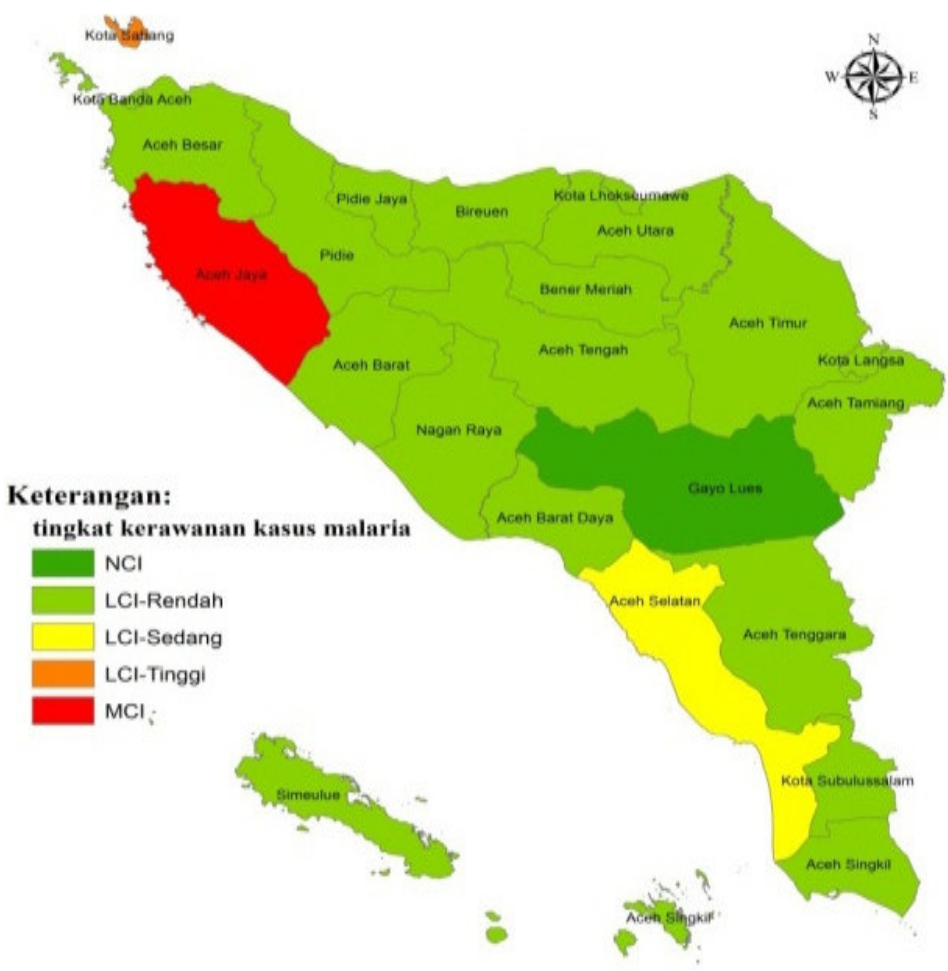

Gambar 3. Peta klasifikasi wilayah Provinsi Aceh berdasarkan tingkat kerentanan kasus malaria 
Berdasarkan Tabel 3 pada kategori 2, diketahui bahwa dari 21 kabupaten/kota yang dianalisis, 19 kabupaten/kota diantaranya termasuk ke dalam cluster 1 (Low Case Incidence Cluster 1) yaitu Kab. Simeulue, Kab. Aceh Singkil, Kab. Aceh Tenggara, Kab. Aceh Timur, Kab. Aceh Tengah, Kab. Aceh Barat, Kab. Aceh Besar, Kab. Pidie, Kab. Bireuen, Kab. Aceh Utara, Kab. Aceh Barat Daya, Kab. Aceh Tamiang, Kab. Nagan Raya, Kab. Bener Meriah, Kab. Pidie Jaya, Kota Banda Aceh, Kota Langsa, Kota Lhokseumawe dan Kota Subulussalam. Selanjutnya terdapat masingmasing 1 wilayah yang termasuk ke dalam cluster 2 (Low Case Incidence Cluster 2) yaitu Kab. Aceh Selatan dan cluster 3 (Low Case Incidence Cluster 3) yaitu Kota Sabang.

Selain itu, Tabel 3 juga menunjukkan bahwa terdapat 1 wilayah yang termasuk dalam kategori 1 (kabupaten/kota yang tidak memiliki kasus malaria sama sekali) yaitu Kabupaten Gayo Lues dan 1 wilayah dalam kategori 3 (Moderate Case Incidence) yaitu Kabupaten Aceh Jaya. Wilayah yang termasuk dalam kategori 3 merupakan wilayah dengan kasus kerentanan penyakit malaria yang paling tinggi diantara kategori lainnya di Provinsi Aceh. Hasil klasifikasi pada Tabel 3 juga dapat ditampilkan dalam bentuk peta pada Gambar 3 .

Gambar 3 menunjukkan klasifikasi wilayah kabupaten/kota di Provinsi Aceh berdasarkan tingkat kerentanan terserang kasus malaria yang dibedakan berdasarkan gradiasi warna. Wilayah yang tidak terdapat kasus malaria sama sekali (kategori 1) diberi warna hijau tua dengan keterangan No Case Incidence (NCI). Warna hijau muda menunjukkan wilayah kabupaten/kota dengan tingkat kerentanan terserang penyakit malaria yang paling rendah (kategori 2 cluster 1) dengan keterangan LCI - Rendah. Warna kuning menunjukkan wilayah dengan tingkat kerentanan terserang penyakit malaria kategori rendah menengah (kategori 2 cluster 2) dengan keterangan LCI-Sedang dan warna orange menunjukkan wilayah dengan tingkat kerentanan terserang penyakit malaria kategori rendah yang paling tinggi (kategori 2 cluster 3 ) dengan keterangan LCI - Tinggi. Sedangkan warna merah menunjukkan wilayah dengan tingkat kerentanan terserang penyakit malaria kategori menengah dengan keterangan MCI (Moderate Case Incidence).

Dengan demikian, dapat disimpulkan bahwa Kabupaten Aceh Jaya, Kota Sabang dan Kabupaten Aceh Selatan merupakan 3 wilayah dengan tingkat kerentanan untuk terserang kasus malaria yang paling tinggi di Provinsi Aceh dibandingkan dengan kabupaten/kota lainnya. Sehingga diharapkan kepada Dinas Kesehatan dan lembaga terkait lainnya, baik di tingkat provinsi maupun ketiga kabupaten/kota tersebut untuk lebih proaktif dalam menangani kasus malaria yang terjadi.

Status kesehatan di suatu daerah dipengaruhi oleh empat faktor yang berhubungan dan saling mempengaruhi yaitu faktor lingkungan, perilaku, pelayanan kesehatan dan keturunan. ${ }^{30}$ Wilayah yang rentan terserang penyakit malaria umumnya berbatasan dengan laut. Habitat perkembangbiakan yang potensial bagi nyamuk Anopheles spp. sebagai vektor penyakit malaria adalah lagun, sungai dan persawahan yang berlokasi dekat dengan garis pantai. $^{31}$ Habitat perkembangbiakan nyamuk Anopheles spp. tersebut lebih banyak pada air yang keruh dan terkena sinar matahari secara langsung. ${ }^{32}$ Selain itu, faktor individual dan perilaku seperti pendidikan, penghasilan, pengetahuan, sikap, tindakan, dan pemakaian kelambu juga berhubungan dengan kejadian malaria. ${ }^{33}$ Sehingga peran aktif masyarakat juga sangat dibutuhkan dalam upaya mendukung program eliminasi malaria terutama di daerah yang rentan untuk terserang kasus malaria.

Pencegahan penyakit malaria merupakan hal yang sangat penting untuk dilakukan oleh pemerintah. Beberapa negara yang mengalami KLB malaria terus berupaya untuk memperketat program pencegahan penyakit malaria seperti yang di lakukan di Negara Republik Zambia dengan program National Malaria Control Strategic Plan yang terdiri dari 4 strategi utama yaitu: pengendalian vektor menggunakan penyemprotan residu dalam ruangan (Indoor Residual Spraying/IRS) dan penggunaan kelambu berinsektisida (Insecticide-Treated Nets/ITNs); manajemen kasus malaria dengan menggunakan diagnosa yang efektif dan terapi kombinasi berbasis obat (Artemisinin-Based Combination Therapy/ACTs); pengendalian malaria pada ibu hamil melalui strategi intermiten pengobatan presumtif (Intermittent Presumptive Treatment/IPTp) dan strategi pemanfaatan informasi, pendidikan, dan komunikasi atau komunikasi perubahan perilaku. ${ }^{34}$

Selain menggunakan strategi pengendalian vektor menggunakan IRS dan ITNs, penggunaan strategi lain seperti pemanfaatan larva dan pengguna metode baru yang sedang dikembangkan di sub-sahara Afrika yaitu house improvement telah menunjukkan adanya perkembangan yang positif dalam mengurangi kasus malaria meskipun masih membutuhkan penelitian lebih lanjut mengenai efektivitas kedua metode tersebut. ${ }^{35}$ Secara umum, upaya pengendalian penyakit malaria telah menunjukkan kemajuan yang sangat berarti dalam 10 tahun terakhir. Setidaknya terdapat 25 projek penelitian vaksin malaria, 47 obat-obatan dan 13 produk pengendalian vektor malaria yang sedang dikembangkan secara global. ${ }^{36}$

Keterbatasan penelitian merupakan hal yang penting untuk disampaikan. Penelitian ini memiliki beberapa keterbatasan, terutama yang berkaitan dengan data penelitian. Data yang digunakan merupakan data sekunder sehingga tidak semua variabel pendukung yang dibutuhkan tersedia, sebagai contoh adalah usia setiap pasien secara terperinci dalam satuan tahun. Selain itu, data kasus penyakit malaria yang tersedia pada masing-masing kabupaten/kota merupakan data agregat, sehingga analisis pada wilayah administrasi yang lebih kecil misalnya kecamatan dan kemukiman (istilah khusus yang digunakan di Provinsi Aceh untuk merujuk pada kumpulan beberapa desa) tidak dapat 
dilakukan untuk melihat gambaran distribusi penyakit malaria di Provinsi Aceh secara lebih mendetail.

\section{SIMPULAN}

Berdasarkan analisis yang telah dilakukan, dapat disimpulkan bahwa 3 jenis parasit plasmodium penyebab kasus malaria tertinggi di Provinsi Aceh adalah plasmodium vivax, plasmodium falcifarum dan plasmodium knowlesi. Analisis K-means clustering menunjukkan bahwa sebagian besar wilayah Provinsi Aceh memiliki tingkat kerentanan yang rendah untuk terserang kasus malaria. 3 wilayah yang paling rentan untuk terserang kasus malaria di Provinsi Aceh adalah Kabupaten Aceh Jaya, Kota Sabang dan Kabupaten Aceh Selatan.

Saran yang dapat diberikan kepada Pemerintah Aceh, terutama Dinas Kesehatan Provinsi Aceh agar dapat memberikan perhatian khusus untuk mengeliminasi kasus malaria di Kabupaten Aceh Jaya, Kota Sabang dan Kabupaten Aceh Selatan yang memiliki tingkat kerentanan terserang kasus malaria yang paling tinggi dibandingkan dengan kabupaten/kota lainnya. Bagi masyarakat yang berdomisili di ketiga wilayah tersebut, diharapkan untuk lebih peduli terhadap faktor-faktor penyebab penyakit malaria dan ikut serta menyukseskan program pemerintah dalam upaya mengeleminasi kasus malaria di Provinsi Aceh.

\section{DAFTAR PUSTAKA}

1. World Health Organization (WHO). Malaria. https://www.who.int/en/news-room/factsheets/detail/malaria. Diakses tanggal 22 Februari 2019.

2. Kemenkes RI. Profil Kesehatan Indonesia 2014. Jakarta: 2015.

3. World Health Organization (WHO). World Malaria Report 2017. Geneva; 2017.

4. Triana D, Rosana E, Anggraini R. Pengetahuan dan Sikap Terhadap Perilaku dalam Penanggulangan Malaria di Kelurahan Sukarami Kota Bengkulu. Unnes Journal of Public Health 2017, 6(2):107112.

5. Badan Perencanaan Pembangunan Nasional. Rencana Pembangunan Jangka Menengah Nasional (RPJMN) 2015-2019 Buku I Agenda Pembangunan Nasional. Jakarta; 2014.

6. Kemenkes RI. Eliminasi Malaria di Indonesia. SK Nomor: 293/MENKES/SK/IV/2009. Jakarta; 2009.

7. Kemenkes RI. Pedoman Surveilans Malaria. SK Nomor: 275/MENKES/SK/III/2007. Jakarta; 2007.

8. Putra TRI. Malaria dan Permasalahannya. Jurnal Kedokteran Syiah Kuala 2011, 11(2):103-114.

9. Babba I. Faktor-faktor Risiko yang Mempengaruhi Kejadian Malaria (Studi Kasus di Wilayah Kerja Puskesmas Hamadi Kota Jayapura). Tesis . Universitas Diponegoro; 2007.

10. Kemenkes RI. Pedoman Penatalaksana Kasus Malaria di Indonesia. Jakarta; 2011.

11. Winardi E. Faktor-faktor yang berhubungan dengan kejadian malaria di kecamatan Selebar kota Bengkulu. Tesis. Universitas Indonesia; 2004.

12. Santi M. Faktor-faktor yang Berhubungan dengan Kejadian Malaria pada Penduduk Kecamatan Lengkong Kabupaten Sukabumi yang Pernah Bermigrasi Tahun 2011. Skripsi. Universitas Indonesia; 2012.

13. Jaringan Survey Inisiatif. Kajian Tematik Program Percepatan Eliminiasi Malaria Di Aceh. Banda Aceh; 2018.

14. Junaidi H, Raharjo M, Setiani O. Analisis Faktor Risiko Kejadian Malaria di Wilayah Kerja Puskesmas Kuala Bhee Kecamatan Woyla Kabupaten Aceh Barat. Jurnal Kesehatan Lingkungan Indonesia 2015, 14(2):40-44.

15. Hadifah Z, Marleta R, Yulidar Y, Fahrni I, Ekowatiningsih R, Wilya V, et al. Penyakit Malaria dan Kepadatan Vektor di Kabupaten Nagan Raya. Banda Aceh; 2012.

16. Wijaya E, Hermasyah H, Yusuf R. Faktor-Faktor yang Berhubungan dengan Kejadian Malaria Berdasarkan Model Community as Partner pada Pekerja Tambang Emas Gunong Ujeun. Jurnal Ilmu Keperawatan. 2017, 5(2):1-13.

17.Muhammad R, Soviana S, Hadi UK. Keanekaragaman jenis dan karakteristik habitat nyamuk Anopheles spp. di Desa Datar Luas, Kabupaten Aceh Jaya, Provinsi Aceh. Jurnal Entomologi Indonesia 2015, 12(3):139-148.

18. Siahaan L. Gejala dan Tanda Klinis Malaria di daerah Endem. Majalah Kedokteran Nusantara 2008, 58(6):211-215.

19. Siahaan L, Yuniarti T. Malaria Pasca Tsunami di Pulau Weh. Kesmas: National Public Health Journal 2008, 2(5):210-214.

20. Asih PB, Rozi IE, Pratama NR, Hidayati AP, Marantina SS, Kosasih S, et al. The baseline distribution of malaria in the initial phase of elimination in Sabang Municipality, Aceh Province, Indonesia. Malaria Journal 2012, 11(1):291-297.

21. Puasa R, Asrul A, Kader A. Identifikasi Plasmodium Malaria di desa Beringin Jaya Kecamatan Oba Tengah Kota Tidore Kepulauan. Jurnal Riset Kesehatan 2018, 7(1):21-24.

22. Falianingrum A, Muludi K, Irawati AR. Perancangan WEB-GIS Penyebaran Wabah Penyakit Demam Berdarah Dengue (DBD) dan Malaria di Kota Bandar Lampung. Jurnal Komputasi 2012, 1(1):23-30.

23. Lind DA, Marchal WG, Wathen SA. Statistical Techniques in Business \& Economics. Fifteenth Edition. New York: McGraw-Hill/Irwin; 2012.

24. Pagano RR. Understanding Statistics in the Behavioral Sciences. Fourth Edition. Eagan, Minnesota: WestPublishing Company; 1994.

25. Nachar N. The Mann-Whitney U: A Test for Assessing Whether Two Independent Samples Come from the Same Distribution. Tutorials in Quantitative Methods for Psychology 2008, 
$4(1): 13-20$.

26. Mau F, Mulatsih M. Perubahan Jumlah Limfosit pada Penderita Malaria Falciparum dan Vivax. Buletin Penelitian Kesehatan 2017, 45(2):97-102.

27. van Wolfswinkel ME, Vliegenthart-Jongbloed K, de Mendonça Melo M, Wever PC, McCall MB, Koelewijn R, et al. Predictive value of lymphocytopenia and the neutrophil-lymphocyte count ratio for severe imported malaria. Malaria Journal 2013, 12(1):101-109.

28. Afdhal MJ, Nurhayati N, Julizar J. Artikel Penelitian Membandingkan Status Hematologis Pasien Malaria Falciparum dengan Vivax di RSUP M . Djamil Januari 2011 - Maret 2013. Jurnal Kesehatan Andalas 2014, 3(3):415-419.

29. Agusta Y. K-Means-Penerapan, Permasalahan dan Metode Terkait. Jurnal Sistem dan Informasi 2007, 3:47-60.

30. Mayasari R, Andriayani D, Sitorus H. Faktor Risiko yang Berhubungan dengan Kejadian Malaria di Indonesia (Analisis Lanjut Riskesdas 2013). Buletin Penelitian Kesehatan 2016, 44(1):13-24.

31. Kazwaini M, Mau F. Hubungan Sebaran Habitat Perkembangbiakan Vektor dengan Kejadian Malaria di Daerah High Incidence Area (HIA) Kabupaten Lombok Tengah Provinsi Nusa Tenggara Barat. Buletin Penelitian Kesehatan 2015, 43(1):23-34.

32. Willa RW, Kazwaini M. Penyebaran Kasus dan Habitat Perkembangbiakan Vektor Malaria di Kabupaten Sumba Timur Provinsi Nusa Tenggara Timur. Jurnal Ekologi Kesehatan 2015, 14(3):218228.

33. Sir O, Arsin A, Syam I, Despitasari M. FaktorFaktor yang Berhubungan dengan Kejadian Malaria di Kecamatan Kabola, Kabupaten Alor, Provinsi Nusa Tenggara Timur (NTT) Tahun 2014. Jurnal Ekologi Kesehatan 2015, 14(4):334-341.

34. Chanda E, Kamuliwo M, Steketee RW, Macdonald MB, Babaniyi O, Mukonka VM. An Overview of the Malaria Control Programme in Zambia. ISRN Preventive Medicine 2013, 2013(Article ID 495037):1-8.

35. Tizifa TA, Kabaghe AN, McCann RS, van den Berg H, Van Vugt M, Phiri KS. Prevention Efforts for Malaria. Current Tropical Medicine Reports 2018, 5(1):41-50.

36. Hemingway J, Shretta R, Wells TNC, Bell D, Djimdé AA, Achee N, et al. Tools and Strategies for Malaria Control and Elimination: What Do We Need to Achieve a Grand Convergence in Malaria? PLoS Biology 2016, 14(3):e1002380. 